\title{
FORMULATION OF EFFERVESCENT TABLET OF TEMULAWAK EXTRACT (Curcuma xanthorrhiza Roxb.) WITH VARIATION OF STEVIA AS SWEETENER
}

\author{
Cessa Lynatra, Wardiyah, Yetri Elisya \\ Jurusan Farmasi, Politeknik Kesehatan Kemenkes Jakarta II, \\ J1. Percetakan Negara No 23. Jakarta Pusat, 10560 \\ Email : diahapt@gmail.com
}

\begin{abstract}
The effervescent tablet containing extract of temulawak (Curcuma xanthorrhiza Roxb.) with variation of stevia sweetener has been formulated using wet granulation method. This research aims to find the formulation of effervescent tablet of temulawak extract (Curcuma xanthorrhiza Roxb.) with the variation of stevia sweetener that meets the requirements of physical tablet test. The effervescent tablet formula was made in three formulas with the difference in the stevia content. Tests conducted include visual tests, uniformity test, hardness test, friability test, $\mathrm{pH}$ test and solubility test. Based on the test results on the physical properties of tablets, it is known that all the formula meets the physical test of tablets and the preferred formula is formula 3 with $4 \%$ of stevia.
\end{abstract}

Keywords: effervescent tablet, temulawak, stevia

\section{FORMULASI TABLET EFFERVESCENTEKSTRAK TEMULAWAK (Curcuma Xanthorrhiza ROXB.) DENGAN VARIASI KADAR PEMANIS GULA STEVIA}

\begin{abstract}
ABSTRAK
Telah dilakukan penelitian tablet effervescent ekstrak temulawak (Curcuma xanthorrhiza Roxb.) dengan variasi kadar pemanis gula steviamenggunakan metode granulasi basah. Tujuan dari penelitian ini adalah untuk mendapatkan formulasi tablet effervescentekstrak temulawak (Curcuma xanthorrhiza Roxb.) dengan variasi kadar pemanis gula steviayang memenuhi syarat uji fisik tablet. Formula tablet effervescent dibuat sebanyak tiga formula dengan perbedaan pada kadar gula stevia sebagai pemanis yaitu formula 1 dengan kadar 1,5\%, formula kadar $2 \%$, dan kadar $4 \%$. Sebagai pembanding dibuat formula 4 dengan pemanis aspartam sebesar $4 \%$. Pengujian yang dilakukan meliputi uji visual, uji keseragaman bobot, uji keseragaman ukuran, uji kekerasan, uji kerenyahan, uji $\mathrm{pH}$ dan uji waktu larut. Berdasarkan hasil pengujian terhadap sifat fisik tablet, diketahui bahwasemua formula memenuhi uji fisik tablet dan formula yang disukai responden adalah formula 3 dengan kadar stevia $4 \%$.
\end{abstract}

Kata Kunci: tablet effervescent, ekstrak temulawak, stevia 


\section{PENDAHULUAN}

Temulawak (Curcuma xanthorrhiza Roxb) merupakan salah satu tanaman obat unggulan Indonesia yang perlu kita kembangkan dan dimanfaatkan oleh masyarakat luas. Berdasarkan data empirik, yaitu pembuktian secara tradisional ataupun data penelitian yaitu pembuktian secara ilmiah yang meliputi penelitian zat aktif dan uji klinik, sampai saat ini diketahui 7 manfaat temulawak yaitu memperbaiki nafsu makan, memperbaiki fungsi pencernaan, memelihara kesehatan fungsi hati, mengurangi nyeri sendi dan tulang, menurunkan lemak darah, antioksidan, membantu memelihara kesehatan, dan membantu menghambat penggumpalan darah.(1)

Rimpang temulawak dilaporkan mengandung kurkuminoid.(2)Rimpang temulawak mengeluarkan bau harum yang tajam. Komponen utama yang terdapat dalam kandungan zat dalam rimpang temulawak adalah kurkumin dan minyak atsiri. Kurkumin berkhasiat sebagai acnevulgaris, anti-inflamasi (anti radang), dan antihepatotoksik (antikeracunan empedu). Kandungan kurkumin dalam rimpang temulawak mencapai 1,6-2,2\% dari berat kering. Minyak atsiri temulawak mengandung felandren, kamfer, borneol, xanthorrhizol, dan sineal.(3)

Tablet effervescent yaitu tablet berbuih dibuat dengan cara kompresi granul yang mengandung garam effervescent atau bahan-bahan lain yang mampu melepaskan gas ketika bercampur dengan air. Dalam perdagangan tablet analgesik yang dibuat alkalis sering dibuat berbuih untuk mendorong lebih cepat hancur dan melarutnya tablet ketika ditambahkan ke dalam air atau minuman yang berair.(4)Effervescent didefinisikan sebagai timbulnya gelembung gas dari cairan sebagai hasil dari reaksi kimia. Tablet effervescent merupakan metode yang nyaman untuk pemberian sejumlah zat aktif atau bahan kimia yang telah diukur sebelumnya dengan disolusi yang relatif cepat. Tablet effervescent tidak ditelan sebelum disolusi. Larutan effervescent berkilau, lezat, dan menyediakan zat aktif dalam bentuk larutan dengan ketersediaan hayati yang terjamin bagi orang yang sulit menelan tablet atau kapsul biasa.(5) Produk olahan temulawak yang ada dipasaran berupa jamu, emulsi, sirup, tablet temulawak, kapsul temulawak, dan serbuk effervescent. Namun, bentuk sediaan 
yang ada saat ini belum mampu menutupi rasa dan bau yang tidak enak dari temulawak. Pada umumnya masyarakat masih mengasosiasikan temulawak sebagai jamu yang mempunyai rasa pahit dan bau yang tidak enak, padahal jika dikonsumsi secara rutin dapat memelihara dan meningkatkan kesehatan. Oleh karena itu, untuk menutupi rasa dan bau yang tidak enak, perlu diformulasikan sediaan yang lebih akseptabel yaitu tablet yang dapat langsung larut dalam air misalnya tablet effervescent dari ekstrak temulawak. Salah satu cara untuk menutupi rasa yang kurang menyenangkan dari obat yaitu dengan penambahan pemanis alami maupun buatan.(6)Namun pada umumnya yang sering digunakan sebagai pemanis pada sediaan tablet adalah pemanis buatan, seperti aspartam dan sakarin. Pemanis buatan termasuk aspartam dibuat dari berbagai bahan kimia yang tak jarang berpotensi menimbulkan efek samping bagi kesehatan. Aspartam mengandung senyawa kimia yang bersifat toksik terhadap organ tubuh seperti asam aspartat, fenilalanin, dan metanol. Kerusakan organ tersebut antara lain pada hati, cairan spinal, kelenjar limfe, paru-paru, jantung, dan lain-lain.(7)
Stevia merupakan pemanis alami yang berasal dari tanaman Stevia rebudiana Bertoni dan telah digunakan oleh beberapa Negara sebagai pemanis alami pengganti gula.(8)Stevia mengandung stevioside yang merupakan bahan pemanis non tebu dengan kelebihan tingkat kemanisan 200-300 kali dari gula tebu dan diperoleh dengan mengestrak daun stevia.(9)Stevia juga tidak rusak pada suhu tinggi seperti sakarin dan aspartam.(8)Keunggulan stevia yaitu tidak menyebabkan kanker (non karsinogenik), karies gigi, dapat mencegah obesitas dan menurunkan tekanan darah tinggi.(10)

\section{METODE PENELITIAN}

\section{Bahan dan Alat}

Ekstrak rimpang temulawak (Curcuma xanthorrhiza Roxb.) dari PT.Borobudur Industri Jamu. gula stevia (PT.Tigapilar Agro Utama), PEG 6000, maltodekstrin, aspartame, asam tartrat dari (PT.Bumi Indah). Asam sitrat, natrium bikarbonat dan PVP dari (PT. Brataco Chemical), aquadest dari (Harum Kimia), orange flavour dan pewarna kuning merek Butterfly.

Neraca analitik, alat-alat gelas, pengayak 12 dan 16 mesh, termometer, 
oven, stopwatch, flower tester, Jolting

Volumeter, mesin cetak tablet, jangka sorong, hardness tester, friability tester, disintegration tester.

\section{Pembuatan Tablet}

Bagian asam dibuat dengan mencampurkanasam sitrat, asam tartrat, dan sebagian ekstrak temulawak hingga homogen. Kemudian siapkan larutan pengikat, tambahkan air sedikit demi sedikit sambil diaduk secara homogen pada serbuk PVP hingga larut, campurkan larutan tersebut kedalam campuran 1 sedikit demi sedikit hingga terbentuk massa basah yang dapat dikepal. Massa kemudian diayak dengan ayakan no.12 mesh dan di oven pada suhu $50^{\circ} \mathrm{C}$ selama 3 jam. Setelah kering ayak dengan pengayak mesh 16 , tambahkan PEG 6000 dan gula stevia.
Kemudian disiapkan komponen basa dengan mencampurkan Natrium bikarbonat dan maltodekstrin hingga homogen. Tambahkan larutan pengikat yang sebelumnya telah ditambah perisa jeruk kedalam campuran 2 sedikit demi sedikit hingga terbentuk massa padat yang dapat dikepal. Massa kemudiam diayak dengan ayakan 12 mesh dan di oven pada suhu $50^{\circ} \mathrm{C}$ selama 3 jam. Setelah kering ayak dengan pengayak mesh 16.

Komponen asam dan basa dicampur dan diayak dengan pengayak mesh 16. Granul yang terbentuk dilakukan evaluasi granul meliputi uji sifat alir, sudut istirahat, indeks kompresibilitas, dan kadar lembab. Campuran granul dicetak dengan mesin pencetak tablet dengan bobot 3000mg tiap tablet.

Tabel 1. Formula tablet effervescent

\begin{tabular}{lllll}
\hline \multirow{2}{*}{ Nama Bahan } & \multicolumn{5}{l}{ Formula (1 tablet) } & & \\
\cline { 2 - 5 } & $\mathbf{1}$ & $\mathbf{2}$ & $\mathbf{3}$ & $\mathbf{4}$ \\
\hline Ekstrak rimpang & $16 \%$ & $16 \%$ & $16 \%$ & $16 \%$ \\
temulawak & & $9,16 \%$ & $9,16 \%$ & $9,16 \%$ \\
Asam sitrat & $9,16 \%$ & $19,16 \%$ & $19,16 \%$ & $19,16 \%$ \\
Asam tartrat & $19,16 \%$ & $32,43 \%$ & $32,43 \%$ & $32,43 \%$ \\
Natrium bikarbonat $32,43 \%$ & $2 \%$ & $4 \%$ & - \\
Stevia & $1,5 \%$ & - & - & $4 \%$ \\
Aspartam & - & $5 \%$ & $5 \%$ & $5 \%$ \\
PEG 6000 & $5 \%$ & $3 \%$ & $3 \%$ & $3 \%$ \\
PVP & $3 \%$ & $1 \%$ & $1 \%$ & $1 \%$ \\
Perisa jeruk & $1 \%$ & $\mathrm{Ad} \mathrm{100 \%}$ & $\mathrm{Ad} \mathrm{100 \%}$ & $\mathrm{Ad} 100 \%$ \\
Maltodekstrin & $\mathrm{Ad} \mathrm{100 \%}$ & & & \\
\hline
\end{tabular}




\section{Pengujian Granul}

1. Uji waktu alir

Massa ditimbang sebanyak 50 gram, ditempatkan dalam alat flower tester pada keadaan tertutup. Penutup dibuka, massa dibiarkan mengalir, waktu dicatat dengan menggunakan stopwatch. Lakukan sebanyak tiga kali dan hitung rata - ratanya. Syarat waktu alir yang baik adalah $\geq 10$ gram/detik.(11)

2. Uji kompresibilitas

Massa dimasukkan ke dalam gelas ukur sebanyak $50 \mathrm{ml}$ yang akan dipasang pada alat bulk density tester, volume awal dicatat. Hidupkan alat, hitung 100 ketukan, volume akhir dicatat. Lakukan terus sampai volume konstan. Jika indeks kompresibilitas adalah 11\%-15\% berarti memiliki sifat kompresibilitas yang baik.(12)

3. Sudut istirahat

Massa ditimbang sebanyak 50 gram, ditempatkan dalam alat flower tester pada keadaan tertutup. Penutup dibuka, massa dibiarkan mengalir. Tumpukan serbuk yang terbentuk diukur tinggi dan jari-jarinya. Hitung dengan rumus sudut istirahat. Sudut istirahat $25^{\circ}-35^{\circ}$ menunjukkan sifat alir yang istimewa.(12)
4. Uji kadar lembab

Ditimbang seksama 5 gram granul kemudian panaskan dalam lemari pengering bersuhu $105^{0} \mathrm{C}$ selama 2 jam. Persyaratan untuk kadar lembab granul effervescent adalah tidak lebih dari 2-4\%.(13)

\section{Pengujian Tablet}

1. Uji Visual

Pengujian dilakukan dengan melibatkan penetapan beberapa parameter, seperti ukuran, bentuk, warna, ada tidaknya bau, rasa, bentuk permukaan, konsistensi dan cacat fisik.

2. Uji keseragaman bobot

Sebanyak 10 tablet diambil secara acak, ditimbang seksama dan hitung rata-rata bobot $(\mathrm{x})$. Hitung harga simpangan baku relatif atau koefisien variasinya $(\mathrm{KV}) .(11)$

3. Uji keseragaman ukuran

Sebanyak 20 tablet diambil secara acak, diukur ketebalan dan diameternya. Ketebalan tablet diukur dengan menggunakan jangka sorong sedangkan untuk diameter tablet diperoleh bersamaan dengan pengujian kekerasan tablet dimana diameter tablet muncul terlebih dahulu sebelum nilai kekerasan 
tablet muncul. Hitung rata - rata ketebalan dan diameternya. Kecuali dinyatakan lain, diameter tablet tidak lebih dari 3 kali dan tidak kurang dari 1 1/3 tebal tablet. (11)

4. Uji kekerasan

Sebanyak 10 tablet diambil secara acak, diukur kekerasannya dengan alat hardness tester, hitung rata ratanya. Kekuatan tekanan minimum tablet adalah sebesar $4 \mathrm{~kg} / \mathrm{cm}^{2}-8$ $\mathrm{kg} / \mathrm{cm}^{2} .(14)$

5. Uji kerenyahan

Sebanyak 10 tablet ditimbang, ditempatkan dalam alat friability tester, kemudian dijalankan sebanyak 100 putaran. Tablet tersebut kemudian dibersihkan dan ditimbang kembali. Kehilangan berat lebih kecil dari $0,5 \%$ sampai $1 \%$ masih dapat dibenarkan.(5)

6. Uji waktu larut

Ambil empat tablet kemudian masukkan masing-masing tablet kedalam beaker glass yang berisi aquadest $200 \mathrm{ml}$ pada suhu $15-25^{\circ}$. Amati waktu yang diperlukan tablet hingga larut sempurna, catat waktu larut tablet. Tidak lebih dari 5 menit.(15)

7. Uji $\mathrm{pH}$

Uji pH larutan effervescent dilakukan dengan cara siapkan beker gelas berisi $200 \mathrm{ml}$ aquadest, larutkan satu tablet effervescent dalam beker gelas kemudian ukur $\mathrm{pH}$ dengan alat $\mathrm{pH}$ meter.

8. Uji tingkat kesukaan

Dengan membagikan kuesioner kepada 30 responden dan lihat tanggapan terhadap ke empat formula. Olah data dan hitung persentase tingkat kesukaan sesuai dengan skala yang telah ditentukan. Responden dipilih secara acak dengan kriteria umur yaitu 14-25 tahun.

Tabel 2. Hasil uji granul effervescent

\begin{tabular}{ccccc}
\hline Formula & $\begin{array}{c}\text { Sudut istirahat } \\
\text { granul }\left({ }^{\circ}\right)\end{array}$ & $\begin{array}{c}\text { Kadar } \\
\text { lembab }(\%)\end{array}$ & $\begin{array}{c}\text { Laju alir } \\
(\mathrm{g} / \mathrm{det})\end{array}$ & $\begin{array}{c}\text { Kompresibilitas } \\
50 \mathrm{ml} \text { serbuk }(\%)\end{array}$ \\
\hline F1 & 26,56 & 2,46 & 21,10 & 14 \\
F2 & 29,05 & 2,63 & 19,84 & 16 \\
F3 & 26,56 & 2,84 & 19,31 & 12 \\
F4 & 26,56 & 2,69 & 18,05 & 12 \\
\hline
\end{tabular}




\section{HASIL DAN PEMBAHASAN}

Tableteffervescent

ekstrak temulawak (Curcuma xanthorrhiza Roxb.) dibuat dengan metode granulasi basah dengan perbedaan formulasitablet pada konsentrasi pemanis alami gula stevia $0,15 \%, \quad 0,2 \%, \quad 0,4 \%$ dan kosentrasi pemanis aspartam $0,4 \%$. Hal tersebut dimaksudkan untuk mendapatkanformula terbaik yang disukai oleh responden dengan penggunaan konsentrasi gula stevia yang berbeda terhadap formulasi tablet effervescentekstrak temulawak.

Berdasarkan hasil evaluasi kadar lembab, kelembaban dari keempat formula berkisar 2-4 \%. Kelembaban dari granul memang di harapkan cukup kecil untuk menghindari reaksi effervescentdini dan sticking. Kadar air yang cukup tinggi dalam granul dapat meningkatkan resiko granul melekat pada punch dan die saat pencetakan, dan dapat menyebabkan terjadinya

Tabel 3. Hasil uji mutu fisik tablet effervescentekstrak temulawak

\begin{tabular}{|c|c|c|c|c|c|c|}
\hline \multirow{2}{*}{ No } & \multirow{2}{*}{ Uji Fisik } & \multirow{2}{*}{ Persyaratan } & \multicolumn{4}{|c|}{ Formula } \\
\hline & & & 1 & 2 & 3 & 4 \\
\hline 1. & Uji Visual & $\begin{array}{l}\text { Bulat, kuning agak } \\
\text { terdapat bercak cokelat, } \\
\text { bau khas. } \\
\text { Larutan jernih berwarna } \\
\text { kuning terang dengan } \\
\text { sisa residu dari } \\
\text { ekstrak,bau khas dan rasa } \\
\text { manis sedikit asam } \\
\end{array}$ & Sesuai & Sesuai & Sesuai & Sesuai \\
\hline \multirow{2}{*}{2.} & \multirow{2}{*}{$\begin{array}{l}\text { Keseragaman } \\
\text { bobot }\end{array}$} & $\mathrm{KV}(<6 \%)$ & 2,65 & 4,65 & 2.58 & 3,87 \\
\hline & & Keterangan & MS & MS & MS & MS \\
\hline \multirow{2}{*}{3.} & \multirow{2}{*}{$\begin{array}{l}\text { Keseragaman } \\
\text { ukuran }\end{array}$} & Rata-rata Diameter & 25,47 & 25,44 & 25,47 & 25,29 \\
\hline & & Rata-rata Tebal & 6,4 & 6,4 & 6,5 & 6,5 \\
\hline \multirow{2}{*}{4.} & \multirow{2}{*}{ Kekerasan } & $4-10 \mathrm{~kg} / \mathrm{cm}^{2}$ & 5,17 & 5,17 & 5,28 & 5,66 \\
\hline & & Keterangan & MS & MS & MS & MS \\
\hline \multirow{2}{*}{5.} & \multirow{2}{*}{ Kerenyahan } & $\leq 0,5 \%-1 \%$ & $0,63 \%$ & $0,91 \%$ & $0,65 \%$ & $0,90 \%$ \\
\hline & & Keterangan & MS & MS & MS & MS \\
\hline & \multirow{2}{*}{ Waktu hancur } & $<5$ menit & $2: 37$ & $3: 23$ & $2: 46$ & $2: 45$ \\
\hline & & Keterangan & MS & MS & MS & MS \\
\hline & Uji pH & $5-6$ & 5,74 & 5,65 & 5,71 & 5,74 \\
\hline & & Keterangan & MS & MS & MS & MS \\
\hline
\end{tabular}

Keterangan: MS = Memenuhi Syarat; TMS = Tidak Memenuhi Syarat 
reaksi kimia yang menyebabkan effervescent tidak stabil. Dari hasil evaluasi kadar lembab, keempat formula tersebut memenuhi syarat.

Sifat alir merupakan faktor penting dalam pembuatan tablet. Aliran yang baik dapat menjamin keseragaman bobot tablet yang dihasilkan. Laju alir yang ditunjukkan pada tabel 4.1 berkisar antara 18,05-21,10 g/detik. Laju alir granul yang baik $\geq 10$ g/detik.(11) Hasil evaluasi dari keempat formula tersebut menunjukkan bahwa keempat formula tersebut memiliki laju alir yang baik, laju alir yang baik dikarenakan ukuran granul yang seragam sehingga granul dapat mengalir dengan baik.

Selain laju alir, sifat alir juga ditentukan oleh sudut istirahat dan indeks kompresibilitas. Semakin kecil

Tabel 4. Hasil uji tingkat kesukaan tablet effervescentekstrak temulawak Tingkat Kesukaan (\%)

Skor Formula Formula Formula Formula

\begin{tabular}{|c|c|c|c|c|}
\hline & 1 & 2 & 3 & 4 \\
\hline 1 & - & - & 43,33 & 16,66 \\
\hline 2 & 23,33 & 26,66 & 26,66 & 43,33 \\
\hline 3 & 30 & 40 & 23,33 & 36,66 \\
\hline 4 & 26,66 & 26,66 & 6,66 & - \\
\hline 5 & 20 & 6,66 & - & 3,33 \\
\hline
\end{tabular}

sudut istirahat yang terbentuk maka semakin baik sifat alir nya.(13) Hasil evaluasi sudut istirahat yang ditunjukkan pada tabel 2 kemungkinan disebabkan ukuran granul dari keempat formula tidak jauh berbeda.

Indeks kompresibilitas keempat formula yang ditunjukkan pada tabel 2 berkisar antara 11-14\%. Uji indeks kompresibilitas juga bertujuan untuk menentukkan sifat granul untuk membentuk massa yang stabil dan kompak bila diberi tekanan. Indeks kompresibilitas $11.14 \%$ memiliki laju alir yang baik. Semakin kecil nilai kompresibilitas, makin besar daya mengalir granul.(13) Dari hasil evaluasi tersebut dapat disimpulkan bahwa keempat formula memenuhi syarat kompresibilitas yang baik.

Uji visual tablet effervescentekstrak temulawak memperlihatkan bahwa tablet yang dihasilkan terlihat kurang homogen, terlihat sedikit poros atau kasar pada permukaannya. Hal ini disebabkan zat aktif temulawak yang dipakai terlalu banyak sehingga menyebabkan kurang homogen, dan kemungkinan kurang nya pelincir pada tablet, sehingga pada waktu dicetak ada granul yang sedikit menempel pada punch. Ruangan yang sulit dikontrol juga menjadi pemicu terjadinya granul 
menyerap air, sehingga menyebabkan granul menempel.

Hasil uji keseragaman ukuran, tablet pada semua formula memiliki diameter yang seragam dengan ketebalan $\pm 0,65 \mathrm{~mm}$. Keseragaman ukuran tablet dapat dilihat dengan membandingkan ketebalan tablet dan diameter. Ukuran tablet terutama ketebalan tablet dipengaruhi oleh jumlah bahan obat yang diisikan ke dalam cetakan serta tekanan saat dilakukan kompresi.(5)Bobot tablet effervescentsebesar $\quad \pm \quad 3000 \quad \mathrm{mg}$ menghasilkan tablet yang memiliki diameter yang sama. Hal ini dikarenakan mesin pencetak tablet rotary yang terdapat pada Laboratorium Farmasi Industri memiliki diameter \pm $25 \mathrm{~mm}$ dengan punch dan die yang telah konstan sehingga ketebalan yang diinginkan tergantung pada volume bahan yang diisikan ke dalam cetakan. Semakin besar bobot tablet yang akan dibuat maka volume tablet pun semakin besar dan sebaliknya. Semua tablet pada tiap formula juga memenuhi persyaratan keseragaman bobot tablet karena memiliki nilai koefisien variasi kurang dari 6\%.Bobot tablet ditentukan oleh banyaknya massa dalam lubang kempa sebelum dikempa. Oleh karena itu, setiap hal yang dapat mengubah proses pengisian lubang kempa dapat merubah bobot tablet yang menimbulkan variasi bobot.(13)

Hasil pengujian kekerasan tablet effervescent pada tabel 3 berkisar antara $5,17 \mathrm{~kg} / \mathrm{cm}^{2}-5,66 \mathrm{~kg} / \mathrm{cm}^{2}$. Perbedaan pada kekerasan tablet karena tekanan yang diberikan kadang tidak sama, dan factor kinerja mesin pencetak tablet. Dari hasil evaluasi tersebut keempat formula memenuhi syarat kekerasan tablet.

Hasil pengujian keregasan tablet effervescent pada tabel 3 berkisar antara 0,3\%-0,9\%.Kerapuhan tablet dapat disebabkan oleh kurangnya daya kohesi yang dibutuhkan tablet agar lebih kompak dan tahan terhadap gangguan secara mekanik. Daya kohesi dapat ditingkatkan dengan meningkatkan konsentrasi bahan pengikat.(13)Kekerasan tablet yang minimal dan tidak terlalu keras tidak cukup untuk melindungi tablet dari pengaruh benturan saat uji kerenyahan. Perbedaan nilai kekerasan berpengaruh terhadap kerenyahan tablet yang dihasilkan. Tablet dengan kekerasan yang kecil cenderung lebih renyah. Dari evaluasi tersebut semua formula memenuhi syarat. 
Hasil uji waktu larut tablet effervescent pada tabel 3 berkisar antara 2,46 detik - 3,23 detik. Tablet effervescent yang baik memiliki waktu larut tidak lebih dari 5 menit dalam 200ml air.(14) Hasil ini menunjukkan keempat formula memiliki waktu larut yang baik. Hasil uji $\mathrm{pH}$ tablet effervescent pada tabel 3berkisar 5,65 5,74. Hasil menunjukkan keempat formula mempunyai $\mathrm{pH}$ yang baik.

Untuk membandingkan respon rasa responden terhadap formula dengan pemanis alami dan buatan maka dibuat formula 4 dengan kadar aspartam sama dengan kadar gula stevia pada formula 3 yaitu 4\%. Dengan kadar yang sama diharapkan kita dapat mengetahui rasa yang paling disukai responden apakah formula dengan pemanis alami yaitu stevia atau pemanis buatan yaitu aspartam. Aspartam dipilih sebagai pembanding karena aspartam sering digunakan sebagai pemanis dalam formulasi sediaan tablet pada umumnya. Berdasarkan tujuan tersebut maka selanjutnya dilakukan uji kesukaan terhadap keempat formula tersebut kepada 30 responden. Responden dipilih secara acak dengan kriteria umur 14-25 tahun. Responden kemudian diminta tanggapannya terhadap formula yang telah dicoba dan mengisi tanggapan nya di lembar kuesioner yang telah di berikan. Data kemudian di olah untuk mengetahui formula mana yang paling disukai oleh responden. Hasil uji kesukaan rasa pada tabel 4 menunjukkan pada formula $123,33 \%$ responden menyatakan suka terhadap rasa sediaan. Formula 2 responden $26,66 \%$ menyatakan suka. Formula 3 $43,33 \%$ responden menyatakan sangat suka, dan 26,66 \% menyatakan suka. Formula $4 \quad 16,66 \%$ responden menyatakan sangat suka dan 43,33\% menyatakan suka. Dari persentase ini menunjukkan formula 3 lebih disukai dibandingkan dengan formula1, 2, dan 4. Hal ini dapat disimpulkan bahwa dengan kosentrasi yang sama yaitu $4 \%$, formula 3 dengan gula stevia lebih disukai daripada formula 4 dengan aspartam.

\section{SIMPULAN}

Granul effervescent temulawak yang dibuat dalam tiga formula dengan kosentrasi kadar pemanis alami stevia yang berbeda memnuhi syarat evaluasi granul dan satu formula pembanding dengan pemanis aspartam memenuhi syarat evaluasi granul. tablet effervescent temulawak formula F1, F2, 
F3, dan F4 memenuhi semua syarat evaluasi tablet. Formula 3 lebih disukai dibandingkan dengan formula 1,2 , dan 4 dengan kadar gula stevia $4 \%$.

\section{DAFTAR PUSTAKA}

1. Anonim. Informasi Temu Lawak Indonesia. Jakarta: BPOM RI; 2006.

2. Yoganingrum A, Purnomowati S. Tinjauan Literatur Temulawak (Curcuma xanthorriza Roxb.). Jakarta: Pusat Dokumentasi dan Informasi Lembaga Ilmu Pengetahuan Indonesia; 1997.

3. Santoso HB. Ragam dan Khasiat Tanaman Obat Sehat Alami dari Halaman Asri. Jakarta: Agromedia Pustaka; 2008.

4. Sukardi, Puteri SAK, Taryana A. Analisis Kelayakan Industri Tablet Effervescent dari Ekstrak Temulawak ( Curcuma xanthorrhiza Roxb ). 2001;162-73.

5. Ansel H. Pengantar Bentuk Sediaan Farmasi. 4th ed. Jakarta: UI Press; 1989.

6. Aminah S, Yanis M, Ramdhan T. Teknologi Pembuatan Effervescent Instan Jahe. Jakarta: Balai Pengkajian Teknologi Pertanian; 2011.

7. Monte WC. Aspartame: Methanol and the Public Health. J Appl Nutr [Internet]. 1984;36(1). Available from: http://www.while-sciencesleeps.com/pdf/1.pdf

8. Raini M, Isnawati A. Kajian:Khasiat dan Keamanan Stevia sebagai Pemanis Pengganti Gula. Media Litbang Kesehat. 2011;21(4):145-56.

9. Wuryantoro H, Susanto WH. Penyusunan standard operating prosedures industri rumah tangga pangan pemanis alami instan sari stevia (Stevia rebaudiana). J Pangan dan Agroindustri. 2014;2(3):76-87.

10. Chandra A. Studi awal ekstraksi Batch daun Stevia rebaudiana dengan variabel jenis pelarut dan temperatur ekstraksi. 2015;1(Luqman 2007):114-9. Available from: http://biodiversitas.mipa.uns.ac.id/ M/M0101/M010119.pdf

11. Anonim. Farmakope Indonesia. V. Jakarta: Kementerian Kesehatan RI; 2014.

12. Aulton M. Pharmaceutics: the Science of Dosage Form Design. 2nd ed. Edinburgh: Churchill Livingstone; 2002.

13. Lachman L, Lieberman H. Teori dan Praktek Farmasi Industri. 2nd ed. Jakarta: UI Press; 1994.

14. Parrot E. Pharmaceutical Technology. United States of America: Burgess Publishing Company; 1970.

15. British Pharmacopeia Commission. British Pharmacopeia. London: The Stationery Office Limited; 2001. 